\title{
Slender False Brome (Brachypodium sylvaticum, Poaceae), an Invasive Grass New to Ontario, Canada
}

\author{
Brian M. Miller ${ }^{1}$, Robert J. AitKen ${ }^{1}$, Michael J. Oldham ${ }^{2}$, and Anton A. RezniceK ${ }^{3}$
}

${ }^{1}$ Aboud \& Associates Inc. (Consulting Arborists, Ecologists and Landscape Designers), 591 Woolwich Street, Guelph, Ontario
N1H 3Y5 Canada; email: brian.miller063@gmail.com and robaitken@ trentu.ca
${ }^{2}$ Ontario Natural Heritage Information Centre, Ontario Ministry of Natural Resources, 300 Water Street, Peterborough, Ontario
K9L 1C8 Canada; email: michael.oldham@ontario.ca
${ }^{3}$ University of Michigan Herbarium, 3600 Varsity Drive, Ann Arbor, Michigan 48108-2287 USA; email: reznicek@umich.edu

Miller, Brian M., Robert J. Aitken, Michael J. Oldham, and Anton A. Reznicek. 2011. Slender False Brome (Brachypodium sylvaticum, Poaceae), an invasive grass new to Ontario, Canada. Canadian Field-Naturalist 125(3): 235-240.

Brachypodium sylvaticum, Slender False Brome, an invasive Eurasian grass, is reported for the first time in Ontario and eastern Canada from Grey County, southern Ontario. The only previous Canadian record is from Vancouver Island, British Columbia. The species is widespread in the U.S. Pacific Northwest, where it is spreading aggressively throughout much of western Oregon. In the eastern U.S.A., known populations are few and localized, although the species will likely spread.

Key Words: Brachypodium sylvaticum, Slender False Brome, Poaceae, invasive, new record, Grey County, Ontario, Canada.

The invasive Eurasian grass species Brachypodium sylvaticum (Huds.) P. Beauv. (Slender False Brome) was recently discovered in Ontario, and is here reported as new to the flora of the province and eastern Canada. On 5 and 19 August 2011, Brian Miller and Robert Aitken encountered an unfamiliar grass species while conducting a volunteer vascular plant inventory of the Nordin Nature Reserve, a 13.5 ha parcel of land owned by the Escarpment Biosphere Conservancy in Grey County, Ontario. A specimen was collected and photographs were taken (Figure 1). Photographs were emailed to Michael Oldham of the Ontario Natural Heritage Information Centre, who was also unfamiliar with the grass. Oldham forwarded the photographs to Anton Reznicek of the University of Michigan. Reznicek provided a tentative identification of Brachypodium sylvaticum, a species previously unreported in Ontario. Miller, Aitken, and Oldham visited the site on 18 October 2011 and confirmed that the unknown grass was B. sylvaticum. Additional specimens were collected by Oldham at this time and have been deposited in regional herbaria (herbarium acronyms follow Thiers 2011*) (see voucher specimens below). The general location of Brachypodium sylvaticum collected in Grey County, southern Ontario, is plotted on the map in Figure 2.

Brachypodium sylvaticum (Huds.) P. Beauv. is a perennial grass native to Europe, Asia, and North Africa (Piep 2007). Only subspecies sylvaticum is known to be present in North America (Piep 2007). The species was first found in North America near Eugene, Lane County, Oregon, in 1939 (Kaye 2001*), and by 1966 it was thoroughly naturalized and formed at least two large colonies in the Corvallis-Albany area of Benton County, Oregon (Chambers 1966). In western North
America, it was subsequently discovered in San Mateo County, California, in 2003 (Johnson 2004) and near Cowichan Lake, Vancouver Island, British Columbia, in 2008 (Fenneman 2010*). It is now also known from the state of Washington (Daniel and Werier 2010). Unconfirmed reports exist for Colorado and Utah (Kaye 2001*; Piep 2007). Brachypodium sylvaticum is highly invasive in the Pacific Northwest. It currently covers an estimated 10000 ha of forested and open habitats in Oregon (Kaye 2003*). By examining nuclear microsatellites and chloroplast haplotype variation in 23 introduced populations of B. sylvaticum in western North America and 25 native populations of B. sylvaticum in western Europe, Rosenthal et al. (2008) suggested that there were two independent historical introductions of the species in Oregon and a separate introduction in California.

Brachypodium sylvaticum is rare in eastern North America. There are no previous reports of B. sylvaticum from Ontario (Dore and McNeill 1980; Morton and Venn 1990; Newmaster et al. 1998) or elsewhere in Canada east of Vancouver Island (Scoggan 1978-1979; Kartesz 1999; Brouillet et al. 2011*). In the eastern U.S.A., B. sylvaticum is currently highly localized. It was first reported in Virginia (Piep 2007) and has recently been reported from Genesee County and Tompkins County in New York State (Daniel and Werier 2009, 2010). It is well established at Bergen Swamp in Genesee County, where it has been present since at least the mid-1990s (Daniel and Werier 2010). In Michigan, B. sylvaticum is known from Benzie County, where it was first collected in 1984 (Reznicek et al. $2011 *$ ).

The Ontario population of Brachypodium sylvaticum is located between Priceville and Flesherton in Grey 


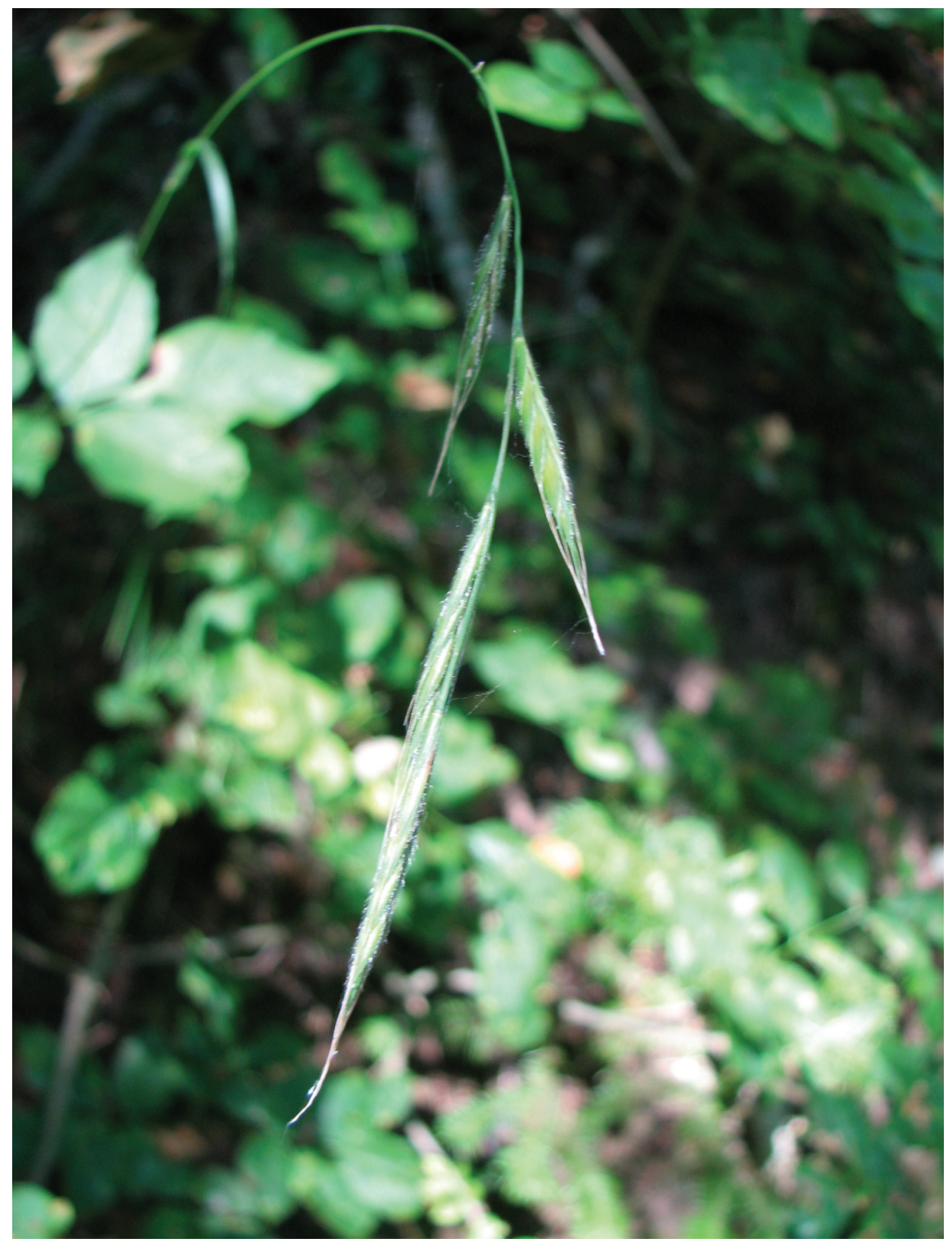

FIGURE 1. Spikelets of Brachypodium sylvaticum in Grey County, Ontario, 19 August 2011. Photo: Brian Miller. 


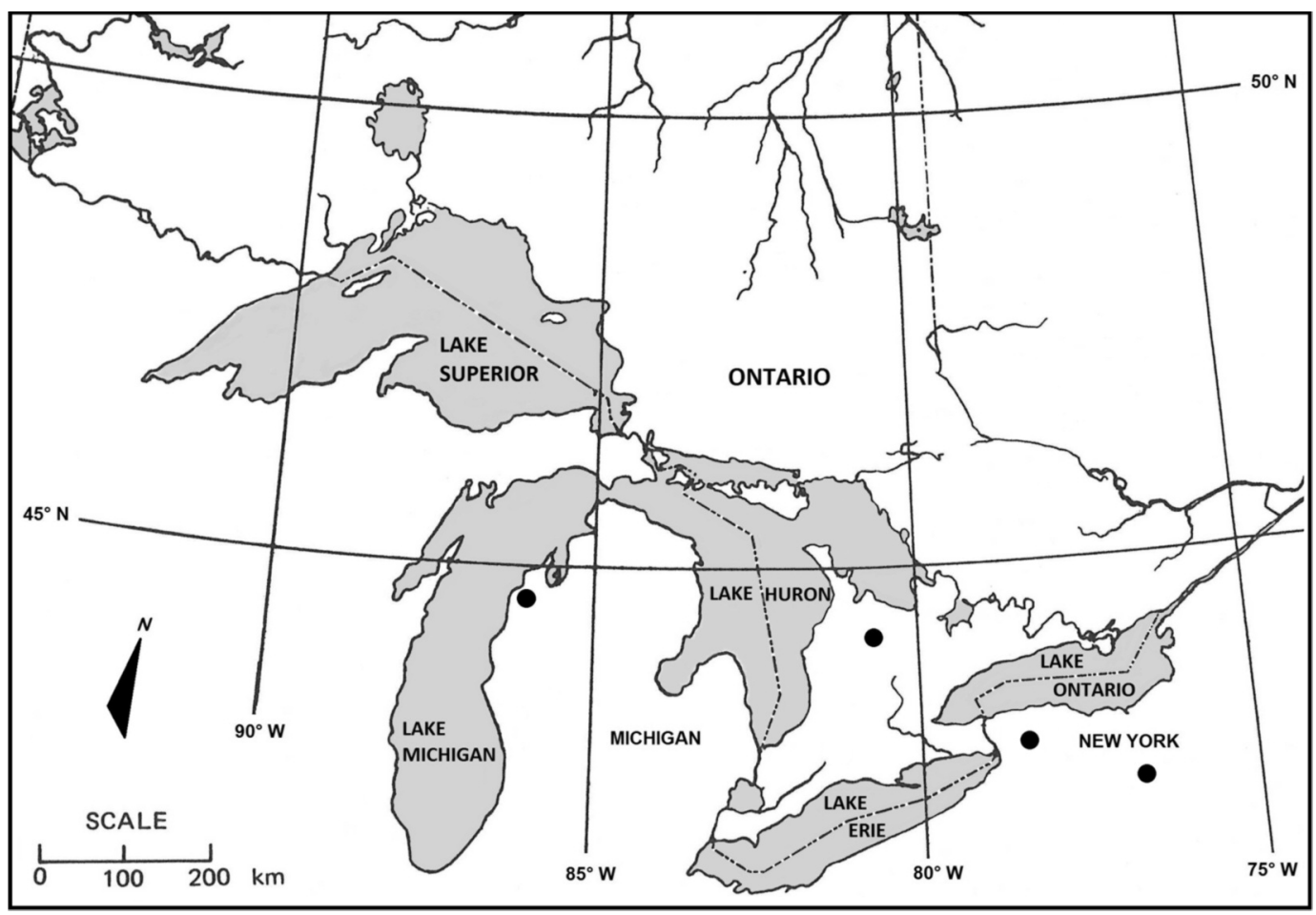

FIGURE 2. General locations of Brachypodium sylvaticum in Grey County (Ontario), Benzie County (Michigan) and Genesee and Tompkins Counties (New York). Base map source: Dore and McNeill (1980).

County south of Grey Road 4 ( $\left.44.217^{\circ} \mathrm{N}, 80.597^{\circ} \mathrm{W}\right)$. In the Nordin Nature Reserve, the population occurs on a small wooded upland knoll dominated by an understory of Eastern White Cedar (Thuja occidentalis) and Balsam Fir (Abies balsamea) and a semi-open canopy of Sugar Maple (Acer saccharum), Paper Birch (Betula papyrifera), Yellow Birch (B. alleghaniensis) and Eastern Hop-Hornbeam (Ostrya virginiana). The knoll is surrounded by a large swamp dominated by Eastern White Cedar, Black Ash (Fraxinus nigra), and Red Maple (Acer rubrum). Several thousand plants of Brachypodium sylvaticum were estimated to occur on the upland knoll; none were observed growing in the surrounding wetland (Figure 3). All vascular flora observed growing on the knoll with $B$. sylvaticum is listed in Table 1.

TABlE 1. Plant species observed growing with Brachypodium sylvaticum in Grey County, Ontario, in 2011.

Scientific name (common name)Scientific name (common name)

Abies balsamea (Balsam Fir)

Acer saccharum (Sugar Maple)

Actaea pachypoda (White Baneberry)

Agrimonia gryposepala (Tall Agrimony)

Betula alleghaniensis (Yellow Birch)

Betula papyrifera (Paper Birch)

Brachyelytrum sp. (Shorthusk)

Carex arctata (Drooping Woodland Sedge)

Carex gracillima (Graceful Sedge)

Carex pedunculata (Long-stalked Sedge)

Clinopodium vulgare (Wild-basil)

Danthonia spicata (Poverty Oat Grass)

Diervilla lonicera (Northern Bush-honeysuckle)

Epipactis helleborine * (Helleborine)
Fraxinus sp. (ash species)

Leucanthemum vulgare * (Oxeye Daisy)

Ostrya virginiana (Hop Hornbeam)

Polygala paucifolia (Gaywings)

Polygonatum pubescens (Hairy Solomon's-seal)

Prunella vulgaris (Heal-all)

Pteridium aquilinum (Bracken Fern)

Schizachne purpurascens (False Melic Grass)

Solidago canadensis (Canada Goldenrod)

Solidago rugosa (Rough-stemmed Goldenrod)

Symphyotrichum urophyllum (Arrow-leaved Aster)

Thuja occidentalis (Eastern White Cedar)

Viola $\mathrm{cf}$. labradorica (Violet)

* Non-native (exotic) species 


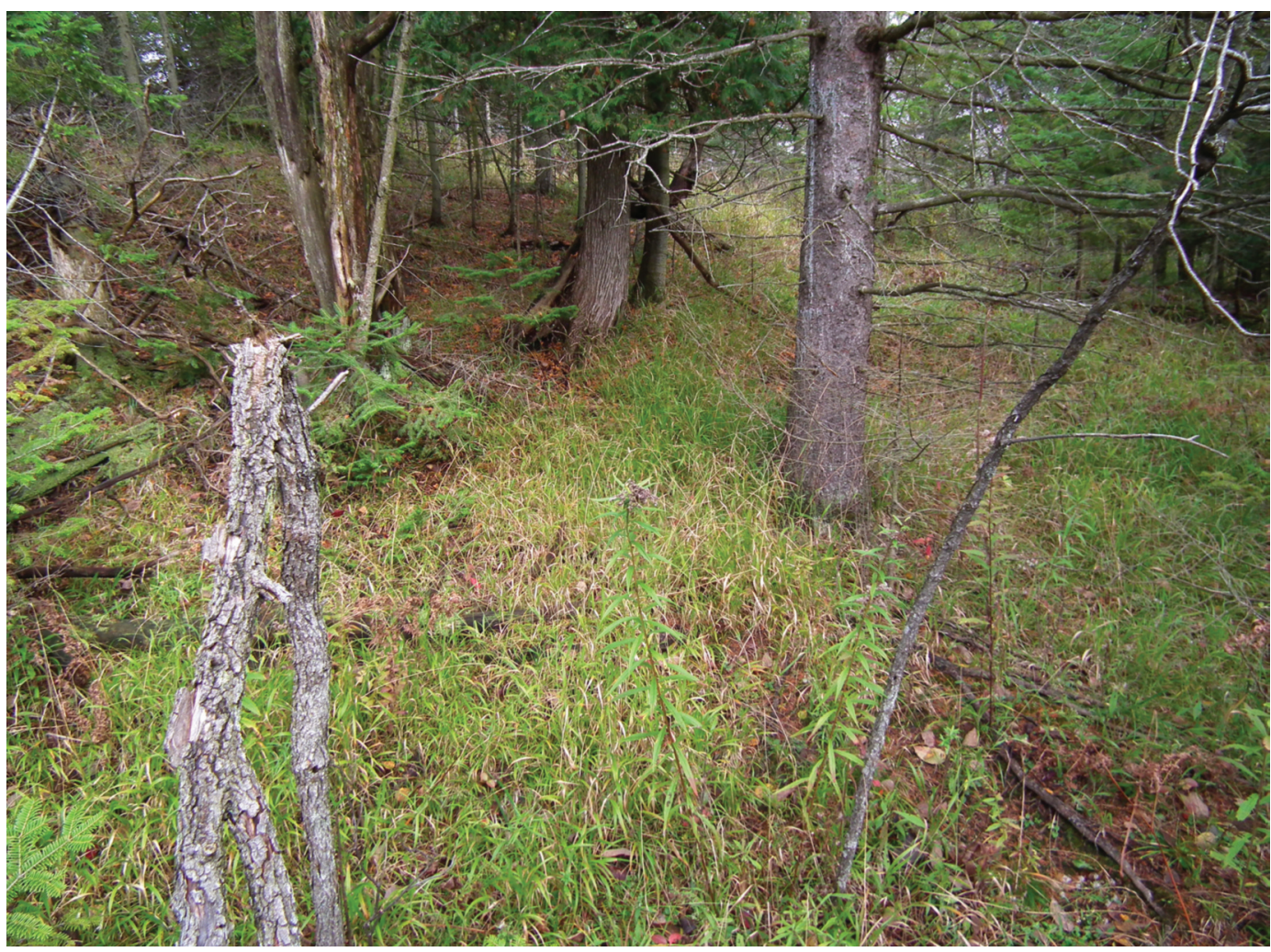

FIGURE 3. Brachypodium sylvaticum (Slender False Brome) population in Grey County, Ontario, 18 October 2011. The graminoid vegetation in the foreground and right side of the photo is almost entirely Brachypodium sylvaticum. Photo: Michael Oldham.

In the flora of Ontario, Brachypodium sylvaticum most closely resembles species in the genus Bromus, particularly Bromus pubescens (Hairy Woodland Brome), due to its hairy leaves and spikelets. However, Brachypodium can be distinguished from Bromus by its open leaf sheaths (closed in Bromus) and spikelets arising singly from the rachis on short pedicels (branched inflorescences in Bromus). The only other Brachypodium species in eastern North America, Brachypodium pinnatum (Heath False Brome), is rare in disturbed ground and waste areas in Massachusetts (Haines 2011). It can be distinguished from Brachypodium sylvaticum by its rhizomes, usually hairless culms and leaf sheaths, stiffer racemes, and short or absent lemma awns (Piep 2007; Paszco 2008).

In its native range in Eurasia, Brachypodium sylvaticum is a forest understory plant, but it also occurs in open grassland (Shouliang and Phillips 2006; Stace 2010). B. sylvaticum is considered highly invasive in the U.S. Pacific Northwest, where it has rapidly expanded its range, thrives in a variety of ecological conditions, and often forms dense monospecific stands (Kaye 2001*, 2003*; Johnson 2004). Preliminary observations suggest this plant is quite invasive in New
York State as well (Daniel and Werier 2010). Observations of the Ontario population, where B. sylvaticum forms a dense, monospecific stand on the east side of the knoll and appears to be spreading to other areas of the knoll, support this suggestion. Although new aliens appear regularly in the flora of eastern Canada, many are highly localized and do not pose a threat to native biodiversity. Brachypodium sylvaticum is a potentially serious invader of natural communities in Ontario. A variety of control methods are being researched and used in the U.S. Pacific Northwest to try to control the species (see the web page of the Falsebrome Working Group: http://www.appliedeco.org/ invasive-species-resources/FBWG).

The origin of the Grey County, Ontario, population of Brachypodium sylvaticum is unknown. Invasion via an abandoned railway line (now a walking trail) that runs approximately $100 \mathrm{~m}$ south of the population is possible; however, no sign of $B$. sylvaticum was observed along the former railway or along Grey County Road 4, located approximately $350 \mathrm{~m}$ to the northeast. Additionally, recreational activities (e.g., hiking) do not appear to have initiated this population-the vegetation surrounding the knoll is thick and undis- 
turbed, and there are no formal or informal footpaths. Seeds may have been dispersed to the site from an undiscovered population in the general area. In the U.S. Pacific Northwest, long-distance seed dispersal of $B$. sylvaticum is usually associated with logging activities, roadside maintenance, and recreational activities (e.g., hiking), with short-distance dispersal occurring via wildlife, particularly ungulates (Fenneman 2010*). White-tailed Deer (Odocoileus virginianus) are common in the vicinity of the Grey County population, and they may be responsible for local dispersal.

Brachypodium sylvaticum should be watched for elsewhere in southern Ontario and eastern Canada. Populations should be controlled wherever possible in order to prevent the widespread invasion of the species in eastern North America, as has occurred in Oregon and other areas of the Pacific Northwest.

\section{Voucher specimens Poaceae}

Brachypodium sylvaticum (Huds.) P. Beauv. (Slender False Brome) - ONTARIO: Grey County, Municipality of Grey Highlands (former Township of Artemesia), Nordin Nature Reserve (Escarpment Biosphere Conservancy), $\sim 2.5 \mathrm{~km}$ northeast of Priceville (or $6 \mathrm{~km}$ southwest of Flesherton) south of Grey Road 4 and north of Durham Road, patches of this grass in the bottom to mid-slope section of a distinct wooded knoll surrounded by Thuja occidentalis swamp and Fraxinus nigra swamp, associated species observed at this location were Pteridium aquilinum, Carex gracillima, Carex arctata, Actaea pachypoda, Polygonatum pubescens, and Polygala paucifolia, $44.217^{\circ} \mathrm{N}, 80.597^{\circ} \mathrm{W}$, 19 August 2011, B. Miller (OAC); ONTARIO: Grey County, Municipality of Grey Highlands (former Township of Artemesia), Nordin Nature Reserve (Escarpment Biosphere Conservancy), $\sim 2.5 \mathrm{~km}$ northeast of Priceville (or $6 \mathrm{~km}$ southwest of Flesherton) south of Grey Road 4 and north of Durham Road, locally common, several thousand plants estimated on wooded knoll dominated by Eastern White Cedar and Balsam Fir, with Pteridium aquilinum, Brachyelytrum sp., Schizachne purpurascens, Epipactis helleborine, Solidago rugosa, Prunella vulgaris, $44.217^{\circ} \mathrm{N}, 80.597^{\circ} \mathrm{W}$, 18 October 2011, M. J. Oldham, B. M. Miller, and R. J. Aitken 39441 (CAN, DAO, MICH, NHIC, TRT, UWO).

\section{Acknowledgements}

We thank the Escarpment Biosphere Conservancy for permission to visit the Nordin Nature Reserve. Carolyn Callaghan, Paul Catling, Jacques Cayouette, and Jeffery Saarela provided helpful comments on the manuscript.

Documents Cited (marked * in text)

Brouillet, L., F. Coursol, M. Favreau, M. Anions, P. Bélisle, and P. Desmet. 2011. VASCAN, the Database of
Vascular Plants of Canada. http://data. canadensys.net/ vascan (accessed 2 December 2011).

Fenneman, J. 2010. Brachypodium sylvaticum in British Columbia. BEN (Botanical Electronic News) No. 425. April 14, 2010. http://www.ou.edu/cas/botany-micro/ben/ ben425.html (accessed 2 December 2011).

Kaye, T. 2001. Brachypodium sylvaticum (Poaceae) in the Pacific Northwest. BEN (Botanical Electronic News) No. 277. November 29, 2001. http://www.ou.edu/cas/botanymicro/ben/ben277.html (accessed 2 December 2011).

Kaye, T. 2003. Invasive Plant Alert. False-brome (Brachypodium sylvaticum). False-brome Working Group. http:// www.appliedeco.org/invasive-species-resources/FBWG/ brsybrochure.pdf (accessed 2 December 2011).

Reznicek, A. A., E. G. Voss, and B. S. Walters. 2011. Michigan Flora Online. University of Michigan Herbarium. http://michiganflora.net/species.aspx $? \mathrm{id}=2026$ (accessed 2 December 2011).

Thiers, B. 2011. Index Herbariorum: A global directory of public herbaria and associated staff. New York Botanical Garden's Virtual Herbarium. http://sciweb.nybg.org/science 2/IndexHerbariorum.asp (accessed 2 December 2011).

\section{Literature Cited}

Chambers, K. L. 1966. Notes on some grasses of the Pacific Coast. Madroño 18: 250-251.

Daniel, S., and D. Werier. 2009. Slender False Brome (Brachypodium sylvaticum ssp. sylvaticum), a new invasive plant in New York. Solidago (Newsletter of the Finger Lakes Native Plant Society) 10(3): 1, 12-13.

Daniel, S., and D. Werier. 2010. Slender False Brome (Brachypodium sylvaticum $\mathrm{ssp}$. sylvaticum), a new invasive plant in New York. NYFA (New York Flora Association) Newsletter 21(1): 1-5.

Dore, W. G., and J. McNeill. 1980. Grasses of Ontario. Monograph 26. Biosystematics Research Institute, Ottawa, Ontario. Research Branch, Agriculture Canada. 566 pages.

Haines, A. 2011. Flora Novae Angliae, A Manual for the Identification of Native and Naturalized Higher Vascular Plants of New England. Yale University Press, New Haven and London. 973 pages.

Johnson, J. 2004. Brachypodium sylvaticum (slender false brome). CAL-IPC (California Invasive Plants Council) News 11: 10-11.

Kartesz, J. T. 1999. A synonymized checklist and atlas with biological attributes for the vascular flora of the United States, Canada, and Greenland. First edition. In Synthesis of the North American Flora. Edited by J. T. Kartesz and C. A. Meacham. Version 1.0. North Carolina Botanical Garden, Chapel Hill, North Carolina, U.S.A.

Morton, J. K., and J. M. Venn. 1990. A checklist of the flora of Ontario vascular plants. University of Waterloo Biology Series No. 34, University of Waterloo, Waterloo, Ontario. 218 pages.

Newmaster, S. G., A. Lehela, P. W. C. Uhlig, S. McMurray, and M. J. Oldham. 1998. Ontario plant list. Forest Research Information Paper No. 123, Ontario Forest Research Institute, Ontario Ministry of Natural Resources, Sault Ste. Marie, Ontario. 550 pages + appendices.

Paszco, B. 2008. The variability of natural populations of Brachypodium pinnatum and B. sylvaticum based on morphological features. Acta Societatis Botanicorum Poloniae 77(3): 255-262.

Piep, M. B. 2007. Brachypodium P. Beauv. Pages 187-192 in Magnoliophyta: Commelinidae (in part): Poaceae, part 1. 
Vol. 24 of Flora of North American North of Mexico. Edited by M. E. Barkworth, K. M. Capels, S. Long, L. K. Anderton, and M. B. Piep. Oxford University Press, New York and Oxford.

Rosenthal, D. M., A. P. Ramakrishnan, and M. B. Cruzan. 2008. Evidence for multiple sources of invasion and intraspecific hybridization in Brachypodium sylvaticum (Hudson) Beauv. in North America. Molecular Ecology 17: 4657-4669.

Scoggan, H. J. 1978-1979. The flora of Canada: Parts 1-4. National Museum of Natural Sciences, Publications in Botany No. 7 (1-4), Ottawa, Ontario. 1711 pages.
Shouliang, C., and S. M. Phillips. 2006. Brachypodieae. Pages 368-369 in Poaceae. Vol. 22 of the Flora of China. Edited by Z. Wu, P. Raven, and D. Hong. Missouri Botanical Garden Press, St. Louis, Missouri, U.S.A.

Stace, C. 2010. New Flora of the British Isles. Third edition. Cambridge University Press, Cambridge, England. 1232 pages.

Received 15 December 2011

Accepted 12 January 2012 